\title{
Perverse and Necessary Dialogues in African Philosophy ${ }^{1}$
}

\author{
Jennifer Lisa Vest \\ Department of Philosophy \\ University of Central Florida, USA \\ drvest@earthlink.net
}

Thought and Practice: A Journal of the Philosophical Association of Kenya (PAK)

New Series, Vol.1 No.2, December 2009, pp.1-23

thoughtandpractice@gmail.com OR thoughtandpractice@uonbi.ac.ke

\begin{abstract}
This article examines the concerns and debates that have arisen in African philosophy over the last few decades, and asks whether it continues to be necessary for African philosophy to take on what the author calls "perverse questions" or "perverse preoccupations" with the West. The author argues that to engage and respond to questions about the intellectual capabilities of African thinkers or the possible existence of philosophical resources in African cultures is to respond to perverse questions. To engage in academic dialogues implicitly or explicitly guided by a request or a felt need to justify and defend the very possibility of African philosophy or African rationality is to engage in perverse and unnecessary dialogues. Because these perverse debates often precede, prevent, or condition the formulation of what count as necessary debates, it is important that they be identified and critically assessed, and when possible, dispensed with. Only then can African philosophy pursue necessary and fruitful debates

${ }^{1}$ A version of this paper was first presented at the Ralph Bunche Center for African Studies at UCLA in 2001, and a revised version was later delivered at the ISAPS conference at the University of Dar Es Salaam, Tanzania in 2003.
\end{abstract}


Is it not astonishing that, while we are ploughing, planting, and reaping, ..., constructing bridges, building ships, working in metals,... while we are reading, writing and ciphering, ... having among us lawyers, doctors, ministers, poets, authors, editors, orators and teachers; that, while we are engaged in all manner of enterprises common to other men, ... we are called upon to prove that we are men!... How should I look to-day, in the presence of Americans, dividing, and subdividing a discourse, to show that men have a natural right to freedom? Speaking of it relatively and positively, negatively and affirmatively? To do so, would be to make myself ridiculous... Frederick Douglass: "The Meaning of July Fourth for the Negro"

\section{Introduction}

Am I a human being? Are my thoughts rational? Am I capable of philosophical thought? Is it possible for me to be both an individual woman and a philosopher? Or does my particular identity as Woman? As Black? As African? As Native? foreclose any possibility of my being considered in more general or universal terms as a thinker? These are perverse questions. Others may ask them of me but I will not ask them of myself. Nor will I spend valuable time in dialogue to resolve them. I must begin my intellectual career with certain assumptions about my own capacities, integrity, self worth, and importance in the world. So too should be the case with African philosophy.

In this paper, I argue that dialogues in African philosophy should begin with certain necessary assumptions: we must assume it exists, that it is possible, that it is valuable, that it is important. We must believe that being African does not invalidate a philosophy, deligitimize it or even raise suspicions about its authenticity. Most importantly, I argue, we must not devote all of our intellectual energy to convincing the world that African philosophy is a worthwhile endeavor. To engage and respond to questions about the intellectual capabilities of African thinkers or the possible existence of philosophical resources in African cultures is to respond to perverse questions. To engage in academic dialogues implicitly or 
explicitly guided by a request or a felt need to justify and defend the very possibility of African philosophy or African rationality is to engage in perverse and unnecessary dialogues. Because these perverse debates often precede, prevent, or condition the formulation of necessary debates, it is important that they be identified and critically assessed, and when possible, dispensed with.

African philosophy has much to offer both the African continent and the discipline of Philosophy. This becomes evident when we acknowledge the fact that African philosophers ask new questions, answer old questions in new ways and make important metaphilosophical contributions. Their work provides important critiques of Western philosophy, and also makes available resources and models for Indigenous philosophers in other cultures. Thus the contributions of African philosophers expand the discourse in important ways. Beyond their contribution to the discipline more generally, works by African philosophers also provide necessary critiques of African society, culture, and of the other disciplines studied in African universities. Consequently, the importance of African philosophy both to Africans and to worldwide intellectual discourse cannot be overestimated. It is for this reason that we must not allow colonialist and racist depictions of African culture and rationality to shape the field.

\section{Definition}

For many years, African philosophers from all over the continent have spent a considerable amount of time addressing perverse questions: questions concerned centrally with the rationality, the intellectual capabilities, and the humanity of Africa and her peoples. They have been concerned, either explicitly or implicitly, with what the Philosopher D.A. Masolo has named the "Rationality Debate" (Masolo 1994, 1). Despite the current existence of a healthy academic literature on African philosophy where sixty years ago there was none, we have not yet overcome the perverse preoccupations which constrained and limited the creation of the field. While African philosophy is no longer dominated by explicit questions regarding its possibility, it continues to be shaped by implicit concerns regarding its legitimacy and by assumptions regarding its definition in relation to Western philosophy. These perverse debates are problematic precisely because they forestall the initiation of 
more serious and more creative dialogues on African philosophy. They often obstruct necessary dialogues. Perverse dialogues have the following undesirable results:

* They privilege European/Western cultures and intellectual productions, and seek to define African philosophy in terms of Western definitions and categories.

* They seek to define African (and other non-Western) philosophies in reaction to or in defense against pre-existing representations of the developing world/The Third world/the colonized/Africa/Blackness, etc.

* They give credence to racist questions and assumptions by devoting serious scholarship and discussion to addressing them, when in fact they should be dismissed as illegitimate in origin.

In contrast, Necessary debates are vital to the object of African philosophy, as they privilege Africa and African issues relevant to African intellectual goals and concerns. Necessary debates are defined by the intellectual goals of African philosophers: they are pivotal to lively and engaging discourse, they are vital for Africans- African thinkers, African educational programs and African creative expression. Nobody can define what is necessary for Africans but Africans themselves. African projects of cross-cultural and comparativist philosophy are necessary, but one-sided monologues initiated and instigated by colonizing discourses are not necessary or productive for African philosophy.

Many African philosophers are certain we have dispensed with the substratum debris of an intellectual climate/period when African rationality was still questioned, and yet perverse reverberations remain an integral part of our current discourse, however well disguised. Preliminary debates have provided some contributory structure for the foundation of some of the African philosophy schools of thoughts. While perverse dialogues no longer dominate the field, they have provided motivation for the settling of certain key debates in African philosophy, including the universal/particular debate, the modernity/tradition debate, and the logical/magical debate, among others. 


\section{Colonial Legacy}

The existence of perverse dialogues provides evidence of the continuing legacy of colonialism in the intellectual production of Africans. The colonial condition set the stage for and conditions the creation of post-colonial discourses such as that on the existence and nature of African philosophy. Because of previous and larger claims made by European and British philosophers regarding European superiority and dominance in disciplines such as philosophy and science, African philosophers have felt compelled to prove themselves. Some African philosophers might argue that as a result of this legacy, African philosophers have no choice but to engage in debates which correct previous representations of Africa and African thought as inferior. It could be argued that the post-colonial condition is defined in part by debates such as these, and that undoing the legacy of conquest and colonialism includes an active critique of colonial fictions. I agree with such a claim only if it is used to defend explicit critical responses to portrayals of Africans as sub-rational.

If we can identify the perverse questions of the colonizer for what they are, if we can consciously identify them as rooted in a racist discourse that sought to justify injustice, then it is possible to answer them without making them legitimate. If however we fail to identify the questions as perverse in origin and intent, if we place answering perverse questions at the center of our discourse or if we fail to explain why we are engaging them, there is a risk that the very act of taking such questions seriously will contribute to the perpetuation of Eurocentric representations of Africans and African thought. If African philosophy is to move beyond being merely a neocolonialist response to the Global North, we must actively identify perverse questions, preoccupations and debates in our work.

The Identification of perverse dialogues is important because of the link between them and current notions about development. Notions of development are imbued with proscriptive evaluations and hierarchical categorizations which define Northern countries as normative models of economic and political organization, and by association, intellectual production, for Southern countries. Such a classification is problematic and inaccurate. Rather, Africans have reason to suspect that following in the footsteps of the "West"/North would be detrimental to their progress. What justification can we give for basing our discussions and 
decisions about self-improvement on articulations made by those peoples who enriched themselves at the expense of under-developing others and then naming those "others" as backwards? I would like to suggest that no such justification is possible.

According to Eritrean philosopher Serequeberhan, "in the name of universality of values, European colonialism violently universalized its own singular particularity and annihilated the historicity of the colonized. In this context, western philosophy - in the guise of a disinterested, universalistic, transcendental, speculative discourse - served the indispensable function of being the ultimate veracious buttress of European conquest" (Serequeberhan 1990, 4). We must recognize European philosophy as neither universalizable nor as an appropriate normative model for African philosophy.

Challenging the universalization of all things Europe thus becomes an anti-colonial move for African intellectuals and an important metaphilosophical move for Indigenous philosophers worldwide. The very possibility of Indigenous philosophies of any kind, but particularly those springing from the cultures of the previously colonized, challenges the entire foundation of Western philosophy. As African American philosopher, Lucius Outlaw, suggests, "the question of 'African philosophy' challenges the very idea of Philosophy as it has been construed by... [those] setting the agendas of philosophizing in the West" (Outlaw 1996, 52). Such questioning inspires a deep and thorough examination of the philosophical enterprise as we know it. What is more, as African scholars Valentine Mudimbe and D.A. Masolo have both pointed out, its establishment is also important because of its role in the anti-colonial and post-colonial re-creation and rehabilitation of African and Black identity. ${ }^{2}$

Perverse preoccupations influenced early discussions of African philosophy and the ways in which early sub-debates were decided. Debates on literacy vs. orality, modern vs. traditional sources of philosophy, implicit vs. explicit expressions of philosophy, science vs.

${ }^{2}$ See Lucius Outlaw, On Race And Philosophy. New York : Routledge, 1996; V.Y. Mudimbe, The Invention Of Africa : Gnosis, Philosophy, And The Order Of Knowledge. Bloomington: Indiana University Press, 1988; D.A. Masolo, African Philosophy In Search Of Identity. Bloomington: Indiana University Press, 1994. 
magical epistemologies, and universality vs. cultural particularity have all been shaped by perversity. These discussions were decided in part as a result of intellectual preoccupations with European disciplinary prescriptions. These prescriptions were also instrumental in the definition of many of the African schools of thought such as the Ethnophilosophy, Excavationist, Professional, Cultural, and Sage philosophy schools. While perverse preoccupations have historically constrained and limited what types of debates African philosophers feel they can engage in, a retrospective autocritical evaluation of the philosophical motivations of our work can be achieved only if we are able to evaluate issues and debates within the field with regard to their necessary or perverse elements. ${ }^{3}$

African philosophers who have debated whether or not literacy is necessary for philosophy have been guided by perverse preoccupations with proving Africans were civilized and therefore literate. Those engaged in debates about the importance of traditional vs. modern forms of African philosophy have tended to be preoccupied with distancing African philosophy from traditional beliefs which previously have been used to label Africans as primitive. Arguments about the need for African philosophy to have universal appeal have often been colored by preoccupations with either proving that African philosophy was similar to European and therefore universal, or else arguing that African philosophy is particular to Africans only and therein lies its value. Arguments made regarding the need for a logical or scientific method in African philosophy are likewise colored by preoccupations with proving that Africans are modern and sophisticated, not guided by "prelogical" concerns with intuition and magic.

Necessary debates might include, for example, claims about the efficacy and uses of literacy in philosophy, but such debates would also include arguments about the value of orality and

\footnotetext{
${ }^{3}$ The classification of schools presented here is the author's own. It includes Henry Odera Oruka's categorization into the Professional, Sage and Ethnophilosophy schools, but adds to that a Cultural school meant to designate those philosophers who base their definition of African philosophy on culture, but do not necessarily employ ethnography or anthropological methods. The "Excavationist" school designates those works which seek to examine philosophy in ancient Egyptian and Ethiopian
} texts. 
performance. Arguments for and against literacy would not be based on hierarchical classifications of cultures or with efforts to prove the humanity of Africans. Debates on the relative merits of scientific epistemologies and magico-religious epistemologies would not be guided by unspoken concerns about measuring up to Western definitions of development based on the acquisition of Western technology, nor would they be guided by Christian monotheistic devaluations of spiritist practices as primitive.

\section{Defining African Philosophy}

A critical evaluation of the history of debates in African philosophy will illustrate the pervasiveness of the problem of perversity. Much of the literature in African philosophy until very recently has been preoccupied with the definition of the field. This defining process has included two preliminary, often conflicting projects: that of defining philosophy for Africa and that of defining Africa for philosophy. Debates between Professional or Scientific school philosophers and Cultural or Ethnophilosophers, and later Sage philosophers, have been defined by their differing concerns with these two projects. Thus early Ethnophilosophers were concerned primarily with the creation of discourses, whether philosophical or religious, which were uniquely African. Cultural and Sage philosophers have also been concerned with defining such uniqueness, and have accordingly focused on the creation of discourses that refer primarily to African cultural traditions, whereas Professional school philosophers have concerned themselves with defining what they called universal forms of African philosophy. Such discourses, employing British and Anglo-American methods and topics, sought to guarantee that African philosophy would be identified as philosophy in the same sense in which Western philosophy was.

While adherents of the Professional school (such as Wiredu, Bodunrin, Hountondji and Appiah) have criticized the Ethnophilosophy school (which is identified with thinkers such as Tempels, Mbiti and Kagame) for adopting a methodology that had its origins in the works of Christian missionaries and European anthropologists and thus legitimated racist representations of African rationality, the Professional School has also been criticized for its duplication of Eurocentric definitions of the discipline. Thus it is not any particular school of thought that is guilty of engaging in perverse debates. One school may accuse another of 
slavishly adhering to colonialist or racist parameters in their proposals for the field, but the truth is that perverse dialogues are not school specific. All schools have been influenced by them to some extent (although certainly not all philosophers in each school have).

Neither the Professional nor the Ethnophilosophy or Cultural philosophy schools can be shown to be more anti-colonial, or conversely more neo-colonial than the other, they just have chosen to prove different aspects of the same thesis - a thesis which can be best encapsulated in the phrase, 'We are rational and thoughtful humans with something important to contribute to the world.' Thus on the one hand, the Professional philosophers accuse the Ethnophilosophers and Cultural philosophers of buying into the anthropologist's claims that African thought is devoid of abstract thought, that it is author-less, stagnant and unanimous, and emotional rather than rational. On the other hand, the Cultural philosophers accuse the Professional philosophers of adopting Eurocentric and neocolonial definitions of philosophy, of denying Africa any philosophy apart from what was introduced by the colonialists (Mudimbe 1988; Yai 1977; Sumner 1980). ${ }^{4}$ Even Sage philosophy, straddling some kind of middle ground between the other two schools, was motivated by this subdialogue on rationality. Both Oruka and Gyeke, among others, interviewed sages in an effort to locate "an African Socrates". ${ }^{5}$ Western philosophy and Western definitions of philosophy thus remain reference structures defining the African field, whether they are used as ideals to emulate or as buttresses against which rebuttals are staged. As African American cultural theorist Audre Lorde pointed out so long ago, it is "an old and primary

${ }^{4}$ Mudimbe outlines the criticisms lodged against philosophers like Hountondji and Towa: they have been criticized for "elitism", "western dependency", and neocolonialism by Philosophers Koffi, Abdou, Yai, and others. See V.Y. Mudimbe, Invention of Africa, p.160; O. Yai, "Theory and Practice in African Philosophy: the Poverty of Speculative Philosophy", Second Order Vol.6 No.2, 1977; N. Koffi and T. Abdou, "Controversies sur L'existence d'une Philosophie Africaine”, African Philosophy, Charles Sumner ed. Addis-Ababa: Chamber Printing House, 1980.

5 Africanist philosopher Gail Presbey tells us: "Odera Oruka argued that the impetus for Sage philosophy was to prove to Europeans that Africans could philosophize": see Gail Presbey, "Who Counts as a Sage? Problems in the Further Implementation of Sage Philosophy", Quest Vol. XI, 1/2, 1997, p.53. Presbey is referring to chapter 17 of Oruka's Practical Philosophy, Nairobi: East African Minimum, 1997, (posthumous). 
tool of all oppressors to keep the oppressed occupied with the master's concerns" (Lorde $1984,113)$

\section{Ethnophilosophy School Preoccupations}

The first works in African philosophy, many written by scholars in fields other than philosophy, were labeled Ethnophilosophy by later philosophers. This school is not identical with the Cultural philosophy school, which emerged later and which consists primarily of the works of academic philosophers. Nevertheless, the two schools share some important claims regarding the sources and methods of African philosophy. The foundational Ethnophilosophy texts were important because they were the first to propose the existence of African philosophy, a very radical proposition for its day. However, because these early works were produced by theologians and religious scholars, they were heavily laden with colonialist preoccupations in response to racist representations of Africans. In addition, early work in Ethhnophilosophy was heavily influenced by Christian missionary projects. Because the authors were Christian, they tended to focus their efforts on finding Indigenous religions combatable with a conversion agenda and with rebutting the claims made by other Christians regarding the "heathen," polytheistic, "pagan" or "irreligious" nature of African cultures.

The fact that works produced by Ethnophilosophers were often motivated by a desire to liberate Africans from colonial thought does not save them from perversity. Paulin Hountondji, one of the most severe critics of Ethnophilosophy, admitted that the work of Ethnophilosophers "rehabilitated the black man and his culture from the scorn of which they had until then been victims" (cited in Masolo 1997, 196). Still, despite the anti-colonial and pro-African motivations of many Ethnophilosophers, we must criticize their "declaring difference and repudiating Eurocentrism by retreating into traditional outlooks that extol African values" in an uncritical way (Imbo 1998, 71). If we claim African culture to be valuable only because it is not European culture, we are still trapped in a perverse dialogue with an ever-present colonizer. As Imbo explains, "a declaration of difference is not a declaration of independence if it is merely a reaction to, and is confined within the categories of the West" (Imbo 1998, 71). An autocritical evaluation of African philosophical discourses which seeks to uncover perverse preoccupations will strengthen the anti-colonial 
intellectual project. Whether we are seeking to demonstrate African uniqueness or African sameness, if our efforts are anchored in the substantiation of claims of Black humanity or intellectual ability, they are always already polluted by perversity.

Another example of the effects of such preoccupations can be found in Kagame's exposition of Rwandan Bantu notions of being, in which he sought to find Bantu categories that corresponded to Aristotelian categories of Substance, Place, Time, etc. (Kagame 1956). ${ }^{6}$ According to Masolo, Kagame's efforts to "prove the universality of the principle of unity" required him to argue for "no significant differences in the concepts of Being as they are found in Greek and Bantu systems of thought" (Masolo 1994, 94). Thus, Kagame's explication of Bantu metaphysics is mired in perverse preoccupations with finding an African ontology equal to and similar to that of the Greeks.

Many of the early Ethnophilosophers were religious scholars and theologians (such as Mulago, Bahoken, and Mbiti), who, despite their anti-colonial efforts, were clearly motivated in part by perverse preoccupations. Tempels, Mbiti, Idowu, Mulago and Opoku were all preoccupied with identifying monotheism and Christian-like beliefs in the traditional belief systems of Africans (Tempels 1949; Mbiti 1969; Idowu 1973;Mulago 1955). "The aim of such works has been to prove that Africans have a belief in one Supreme Being." (Masolo 1994, 121) Despite the fact that the victimization of African traditional religions by the "processes of modernization, Europeanization, and colonization," necessitated the reclaiming and rehabilitation of African Gods as integral to the post-colonial healing of African identity, the unjustified preoccupation these scholars demonstrated with monotheism proves problematic given historic evolutionist anthropological representations of civilization in terms of monotheism (Masolo 1994, 122).

Actively expressing the influence of perverse preoccupations affords us the opportunity for deeper theoretical scrutiny.

\footnotetext{
${ }^{6}$ Masolo 1994, 88; Alexis Kagame, La Philosophie Bantu-Rwandaise de Lettre Academie Rotale des
} Sciences Memoires in 8 Nouve, Serie xii, I Brussels. 
Theologian John S. Mbiti, the seminal author of one of the earliest African-authored works on African religion and philosophy, concerned with changing the problematic representations of African philosophy, wrote, "African religions and philosophy have been subjected to a great deal of misinterpretation, misrepresentation and misunderstanding." According to Mbiti, "They have been despised, mocked, and dismissed as primitive and underdeveloped." Yet Mbiti did not believe that traditional religion of Africa is the best religion for Africans. Rather he fully expected Christian convergence to prevail over the continent and celebrated traditional African religions only to the extent that they facilitated the eventual conversion of Africans. According to Mbiti, "Christianity," "holds the greatest and the only potentialities of meeting the dilemmas and challenges of modern Africa." (Mbiti 1969, 362). Because he was, in his own words, "writing as an African Christian... [who] sees his mission as assimilating [the] unique African universe, with its deep religiosity, to the message of Christianity" (Mbiti 1969, 13), and trying "to counteract the myths of the African as a savage incapable of religious sentiment..." his work provides another example of a dialogue with the West responding to racist representations of Africa. He wanted to prove to Westerners that Africans were Christian-like in their religious views and therefore civilized (Imbo 1998, 63).

The Ethnophilosophy School was heavily influenced by the work of Negritude thinkers. Poet and philosopher Leopold Senghor, one of the originators of the Negritude movement, claims to have developed negritude as "a weapon... as an instrument of liberation" (Senghor 1970, 179-92) and "a response to the modern humanism that European philosophers and scientists have been preparing since the end of the nineteenth century..." (Senghor 1970, 184). He defined African thought as "diametrically opposed to the traditional philosophy of Europe" (Senghor 1994, 30). He has been criticized for "endorsing the European definitions of Africa" and agreeing with the Eurocentric view that Africa and Europe are inherently different (Imbo 1998, 14). It has been argued that "Negritude takes back all those features on which eurocentrism placed a negative value" (Imbo 1998, 85) but flips the scrip and embraces these traits as positive and thus claiming for Africans "a different kind of reason." According to Senghor, "European reasoning is analytic, discursive by utilization; NegroAfrican reasoning is intuitive by participation" (Senghor 1964, 74). They are opposites. His 
work agrees on the differences between the cultures and peoples but disagrees on their relative worth. He selects those characteristics traditionally disparaged by racists as proof of Africa's backwardness and lauds them as proof of Africa's unique contribution to the world. Whether one reads this project as anti-colonial or problematically neocolonial in orientation, it's preoccupation with dialoguing with Europe and addressing European definitions of Africa renders it, according to my definition, intellectually perverse.

\section{Excavationist School Preoccupations}

A similar preoccupation with the West is found in the works of some Excavationist School philosophers such as Cheikh Anta Diop and Obenga, among others. The search for a glorious African past, heavily influenced by a desire to 'set the record' straight with regard to where exactly the "cradle of civilization" is, which characterizes the work of Excavationists like Diop, Obenga, and Bilolo, is motivated by a perverse preoccupation with Western claims that Africa lacked civilization. Thus, in his attempts to address longstanding prejudices against African civilization, Diop gets caught up in a "systematic counterEuropean narrative" (Imbo 1998, 71) in order to "explain the contrary view." (Masolo 1994, 18).

Likewise, Obenga, in his dissertation on Ancient African philosophy explains the need to document ancient African philosophic history in terms of the need to prove African rationality. He writes, "All the major issues that have engaged the attention of philosophers in Asia, Europe, America, etc. can be found in African philosophy...Any doubt about the reason and rationality in Africa was chiefly due to anthropological innuendoes. Philosophy as such was not, and has never been, a mystery to the African mind" (Obenga 2004,49)

While scholars like Diop and Olela have been lauded for their efforts to disprove racist accounts of Africa, and while I agree with Masolo's claim that Diop makes a "significant contribution" to an interrogation of eurocentrism and "its pretensions as a dependable source of knowledge about other (non-European) cultures and peoples" (Masolo 1994, 18), the preoccupation Diop has with "countering the Hegelian legacy" renders this project perverse (Masolo 1994, 19) 
There are some Excavationist philosophers who are not trying to prove that Africa has indeed made a contribution to the intellectual history of humanity in response to colonialist claims that Africa lacks the capacity for abstraction. The work of Excavationist Philosopher Teodros Kiros, for example, on the $16^{\text {th }}$ century Ethiopian philosopher Zera Yacob is not guided by a need to respond to racist portrayals (Kiros 2004). However, Excavationist Olela who argues that "the historical foundation of the Modern African World-View as well as that of the Greeks and Romans, came from Ancient Africans" is guided by the desire to defeat "the argument ...that the African mind is in no way capable of any systemic philosophy" (Olela 1998, 43). Why, I ask, must we engage in such ridiculous claims about the intellectual capacities of a whole continent?

\section{Professional School Preoccupations}

The work of the Professional school philosophers is also heavily influenced by perverse preoccupations. In reaction to what they saw as the pitfalls of early works by ethnophilosophers, Professional school philosophers sought to avoid simplistic and uncritical over-valuations of African traditions. Recognizing the trap entailed in defining African philosophy as the antithesis of Western philosophy, they nevertheless fell into their own perverse traps. For example, the work of Professional school philosophers such as Bodunrin and Hountondji was motivated by their desire to disprove western stereotypes that:

* African thought was prelogical, irrational, and non-scientific;

* African culture was particular, subjective, and not universalizable; and thus

* Africans had no heritage of philosophical thought

Their preoccupation with these stereotypes had many implications for the formulation of the field. It has meant, for example, that members of the Professional school have sought to minimize the distinctions between African and Western philosophies in their formulation of an African philosophy that closely resemble mainstream British and Anglo-American forms of philosophical production. Because the explicit debate at the center of early Professional school formulation concerned the universality of philosophy, it was important to members of 
this school that African philosophy have universal value. They gave it universality by universalizing Europe - and therein lies its perversity.

We can see this sentiment expressed, for example, in the work of Benin philosopher Hountondji, who has argued that European philosophy has universal value whereas African philosophy (as defined by the early Cultural philosophers) does not. He is impatient with the lengthy debates that have occurred over the definition of African philosophy, and is urgent about the need for African philosophy to have the same universality that European philosophy has. ${ }^{7}$ It must have the "same universal aims as those of any other philosophy in the world," he writes. Hountondji has been very critical of "ethnophilosophers", whose work, he contends, is colored by their compulsion to dialogue with the West in order to defend and reinvent themselves. This dialogue, he says, "encourages the worst kind of cultural particularism." He doubts whether the word philosophy can "retain its habitual meaning" when qualified by the word "African". He is concerned about the "simple addition of an adjective necessarily chang[ing] the meaning of the substantive." For him, what is at stake in defining an African philosophy unique to Africa, or at least different from the "habitual meaning" (Hountondji 1983, 66) is "the universality of the word 'philosophy' throughout its possible geographical applications" (Hountondji 1983, 56). For Hountondji, a philosophy that is explicitly cultural can never be universal. Like Ghanaian philosopher Appiah, he believes that while themes and questions can vary from philosopher to philosopher and from culture to culture, a single style of inquiry must be preserved. He does not believe we should define such a style of inquiry for Africa: he believes that the best style of inquiry already exists. For him, "the African peoples who take over the theoretical

${ }^{7}$ Most of the early literature on African philosophy was concerned with the questions, "Is there an African Philosophy?" and "How should African Philosophy be defined?" See, for example, C. Momoh, “African Philosophy: Does it Exist?” Diogenes 130, 1985; Anta Diop and I. Okpewho, “The Search for a Philosophy of African Culture", Cahiers d'Etudes Africaines Vol.21 No.4, 1981, p.587-602; Kwasi Wiredu, "On an African Orientation in Philosophy", Second Order: An African Journal of Philosophy, Vol.1 No.2, 1972; H. Odera Oruka, "The Fundamental principles in the Question of African Philosophy", Second Order, No.4, 1975, pp.44-55; Innocent Onyewuenyi, "Is there an African Philosophy?” Journal 
heritage of Western philosophy, assimilating and transcending it, are producing authentic African philosophy" (Hountondji 1983, 67).

Hountondji's adoption of a European universal includes a belief in the relative inferiority of non-European thought. Thus in his critique of Ethnophilosophy, Hountondji insists that proposals for the study of Yoruba, Dogon, or Akan Philosophy are flawed from the beginning because, purportedly, the worldviews of these ethnic groups cannot possibly measure up to Europe. For Hountondji and other Professional School adherents, it goes without saying that European philosophy is the model for all other philosophy, so that to innovate somewhat on this model is all that is necessary to do philosophy in a national (African or non-European) context.

While Hountondji is able to come up with numerous reasons why African philosophy is not universal, he never questions the universality of European or Anglo American Philosophy. Instead, he seeks to show how African philosophy (where it is defined to include traditional Indigenous thought) has failed to live up to the name philosophy precisely because it does not adequately measure up to the work of European and American philosophers such as Hume, Kant, or Spinoza. "What a mockery it is," he writes, “ to compare such ambitious philosophers (e.g. Hegel, Spinoza) with what anthropologists are today presenting to the world as African systems of thought” (Hountondji 1983, 74).

Indeed, for thinkers such as Hountondji, no philosophical manipulation of an African worldview or system of thought can possibly count as philosophy in the universal sense, precisely because in order to be universal, philosophy must begin in modern Europe or North America. That Hountondji subscribes to a European notion of universal philosophy is also evident in the various definitions he gives for what does and does not count as philosophy. For example, he makes scientist-tinged arguments for philosophy, defining it as "no more than reflection on the aims of science" (Hountondji 1983, 73). He also defines science as "a core discipline or subdiscipline of philosophy." (Hountondji 1983 ' p.xiii) 
Likewise, philosopher Anthony Appiah argued for a European universal, insisting that African philosophy must bear a family resemblance to European philosophy. For him, while "Western academic philosophy may have a hard time agreeing on its own definition", it is clear what is not philosophy. "In the Euro-American tradition", he explained, "nothing can count as philosophy, for example, if it does not discuss problems that have a family resemblance to those problems that have centrally concerned those we call 'philosophers"' (Appiah 1989, 110). He asks why, if African philosophy has a different set of problems and/or a different methodology from European philosophy, we should want to call it philosophy at all. He believes that there is a set of universal, "necessary" questions which constitute philosophy. Similarly, Appiah argued that, for example, "the African belief in witchcraft [which is representative of the thought system of Africa] is dogmatic and it makes sense only within one culture and the corresponding conceptual framework. It cannot be translated into or understood within a different cultural scheme; hence it cannot meet the requirements of universal rationality" (Ikuenobe 1997, 192) ${ }^{8}$

Philosopher Peter Bodunrin advances similar arguments. "Any study of traditional society," according to Bodunrin, must "begin by an examination of philosophical issues and conceptions that have loomed largely in the history of world philosophy" "If a problem is philosophical”, he adds, "it must have a universal relevance to all men” (Bodunrin 1991, 173). For him, the history of Western philosophy is the history of world philosophy, and it alone defines what is of 'universal relevance.' For him, there is an antagonistic relationship between the particularity of African culture and the universality of Western culture. He warns, "our culture may be dear to us but truth must be dearer." ${ }^{9}$ He refers to what he calls "the problems of determinism and freedom, the self and consciousness- to which

${ }^{8}$ here, Ikuenobe is referring to the argument that Appiah makes in Necessary Questions, on page 203 Ikuenobe, "Parochial Universalist...”, 192.

${ }^{9}$ This argument is made in the context of his critique of Hallen and Sodipo's discussion of “apparent inconsistencies" in certain Yoruba notions of causation. Barry Hallen andJ.O. Sodipo, Knowledge, Belief and Witchcraft: Analytic experiments in African Philosophy. London: ethnographics, 1986. 
philosophers have not yet found a solution" as "the genuine perennial problems." ${ }^{10} \mathrm{He}$ thus fails to notice the particularly European character of these "perennial" questions. He also limits the field of possible questions to those which European philosophers "have not found a solution to yet" (Bodunrin 1991, 175-6). He believes, as many mainstream philosophers do, that certain questions are already answered - that because certain Western philosophers have addressed certain problems, they are no longer in need of further reflection.

Twenty years after his first publication on the topic, Bodunrin came to the point of admitting that a certain western bias had prevented him from recognizing the existence of nonEuropean forms of philosophy. In a later interview, he admitted that there may be more than one way of doing philosophy, but he still believed that the Western approach was the superior one. In reference to his change of opinion regarding the existence of non-European philosophies, he explained: “...... I agree that the Western is one way of looking at the world, the Chinese is one way of looking at the world, the Islamic is one way of looking at the world, the Christian...But the world cannot stop here. Lets go to the next stage to argue well. You are this way. I am this way and-the way I am is better that (sic) the way you are...we have to be able, however unpleasant it may be to our own cultures, to ourselves, we have to be able to say: A is better than B" (Graness 1996). The extent to which his thinking is colored by a conquering and colonizing European legacy is evident in his determination of which philosophies are best. He went on to explain that the best philosophies can be located by ascertaining the status of the societies in which they are produced. He argues, "You tell me the African way of life has its own logic and so on. Okay, and I ask the question; If it is equally good as the Christian scientific world-view, how is it that this (sic) traditional societies are among the poorest in the world today? How is it that they are among the most backward in the world today?" (Graness 1996). Bodunrin appears to conflate global economics with intellectual ability. For Bodunrin, in his revised

${ }^{10}$ See P.O. Bodunrin, "The Question of African Philosophy", H. Odera Oruka ed. Sage Philosophy, Nairobi: African Center for Technological Studies, 1991, pp.175-6. 
view, the European way of thinking may not be the only way, but it is the only way worth discussing. Like witches, other forms of philosophy, in Bodunrin's estimation, are simply not worth bothering with. He argues his position by asking the rhetorical question, "so, if it is true that we have some superior way of thought, how is it that the West is our head?"11 Bodunrin is not alone in this belief. Philosopher Marcien Towa, also critical of Ethnophilosophy, argues, according to Masolo's discussion, that "the scientific and technological inferiority of Africa or China in comparison with Europe is historical evidence that neither Africans nor the Chinese have had the proper kind of philosophy in their traditional past." 12

In his early work, philosopher Kwasi Wiredu also argued that African philosophy must mimic European and Anglo-American forms. "The African philosopher," deduced Wiredu, “ has no choice but to conduct his philosophical inquiries in relation to the philosophical writing of other peoples, for his own ancestors left him no heritage of philosophical writings." (Wiredu 1998, 98) ${ }^{13}$ Clearly these claims by Professional School philosophers are colored by perverse preoccupations with European definitions of societal development and cultural sophistication defined in terms of the acquisition of Western technology and Christianity. This does not mean that the work produced by Professional School philosophers I not motivated by lofty aims.

\footnotetext{
${ }^{11}$ See Graness 1996.
}

12 See D.A. Masolo, African Philosophy in Search of Identity, p.169. Masolo is here referring to Marcien Towa's publications, Essai Sur la Problematique Philosophique dnas "l'Afrique Actuelle, Yaounde: Cle, 1971 and L'Idee d'une Philosophique Africaine, Yaounde: Cle, 1979.

${ }^{13}$ He defined philosophy as "what modern Professional philosophers produce..." 38. Wiredu, "How Not to Compare African Thought and Western Thought," In African Philosophy, An Anthology, E. Eze ed. 
According to philosopher Fidelis Okafor, the goal of Professional School formulations of philosophy was "to destroy the myth of savagery" perpetuated by the "Colonial West" which portrayed Africans as 'non-rational' (Okafor 1993, 97). Why should Africans prove they are rational, thoughtful, intellectually sophisticated persons? To whom must they prove this? Why must African philosophy be defined in terms of a reaction to foreign misrepresentations? Why must we as Black people devote our greatest minds to engaging in dialogues designed to prove our humanity? I argue that not only are African philosophers under no obligation to engage perverse dialogues but that the project of African philosophy is best served by eschewing such engagement or at the least by being aware of the obfuscating role such dialogues have for African philosophy.

Determining whether or not existing debates are perverse in origin can aid African thinkers in identifying debates that are necessary to the development of the discipline and not merely prompted by external representations and the need to reply to them. If there is a widespread belief in witches in many parts of Africa, perhaps a debate on the ontology of witchcraft is necessary, regardless of how it fits into existing discourses of primitive religions authored by Western writers. If there is a widespread belief in intimate ontological relationships between humans, animals, plants and inanimate objects, then perhaps an African metaphysician should explore this idea, regardless of how it might be disparaged by European thinkers who might classify such beliefs as animistic and therefore not worthy of investigation. Perhaps the ideas of important men and women ought to be studied by Sage philosophers whether or not they can be compared to the ideas of Socrates. Perhaps African languages ought to be studied for their epistemological insights regardless of whether similar insights can be found in Anglo-American Analytic investigations of language. Perhaps African philosophers ought to engage in intercultural dialogues with Asian, Native American and African American philosophers, and no longer focus all of their attention on Western interlocutors. Perhaps efforts such as these will lead to a definition by African philosophers of the Necessary Debates in their field. 


\section{Conclusion}

While engagement in perverse dialogues may have been necessary in the early formulations of African philosophy, there is no reason at this point for African philosophy to continue to allow their ubiquitous influence on it. By becoming aware of the tendency to engage in such dialogues by African philosophers in various schools of thought, we can approach our work more critically and refuse to engage in these preoccupations, thus freeing ourselves to pursue other more important subjects. Checking for perverse preoccupations should be one of the tests each new work in African philosophy is subjected to. We can acknowledge historical misrepresentations and stereotypes without devoting all of our scholarship to disproving them. We can acknowledge the historical centrality of European and British thinkers in the discipline without preserving or reifying that ethnocentrism. We can acknowledge the role and legacy of intellectual colonialism without limiting our works to the exclusive assertion of anti-colonial arguments. A metaphilosophical assessment of perverse preoccupations in the genealogy of African philosophy will clear the way for African philosophy to pursue the debates relevant and necessary to the project of African philosophy.

\section{References}

Appiah, Kwame. 1998. "Ethnophilosophy and its Critics". The African Philosophy Reader. New York: Routledge.

--. 1989. Necessary Questions: An Introduction to Philosophy. Englewood Cliffs, NJ: Prentice Hall.

Bilolo, Mubabinge . 1986. Les Cosmo-Théologies Philosophiques De l'Egypte Antique. Problèmatiques-Prémisses Hermeneutiques-Et-Problèmes Majeurs. Kinshasa: Travaux de l'Académie de la Pensée Africaine, 1.

Bodunrin, P.O. 1990. "The Question of African Philosophy" in H. Odera Oruka, eds. Sage Philosophy. The Netherlands: E.J. Brill.

Diop, Anta and I. Okpewho. 1981. "The Search for a Philosophy of African Culture". Cahiers d'Etudes Africaines 21:587-602.

Douglass, Frederick. 1950. "The Meaning of July Fourth for the Negro". The Life and Writings of Frederick Douglass, Volume II: Pre-Civil War Decade 1850-1860. Foner, Philip S. Ed. New York: International Publishers.

Graness, Anke. 1996. "Interview with professor Peter O. Bodunrin". Quest, Vol.9 No.2 / Vol.10 No.1, 1996, pp.198-210.

Hountondji,Paulin J. 1983. African Philosophy: Myth and Reality. Bloomington: Indiana University Press.

Ikuenbobe, Polycarp. 1997. "The Parochial Universalist Conception of 'Philosophy' and 'African Philosophy'”. Philosophy East \& West, 47; 189-210. 
Imbo, Samuel. 1998. An Introduction to African Philosophy. Lanham: Rowman and Littlefield.

Kagame, Alexis. 1956. La Philosophie Bantu-Rwandaise de L'etre. Brussels : Academie Royale des Sciences Coloniales.

Koffi, N. and T. Abdou. 1980. "Controversies sur L'existence d'une Philosophie Africaine”. African Philosophy. Sumner, Charles Ed. Addis-Ababa: Chamber Printing House.

Lorde, Audre. 1984. “The Master's Tools Will Never Dismantle the Master's House". Sister Outsider. Berkeley: Crossing Press: 110-113.

Masolo, D.A. 1994. African Philosophy In Search Of Identity. Bloomington: Indiana University Press.

Mbiti, John S. 1969. African Religions and Philosophy. London: Heinemann Educational Books.

Momoh, C. 1985. “African Philosophy: Does it Exist?” Diogenes, 33; 73-104.

Mudimbe, V.Y. 1988. The Invention Of Africa: Gnosis, Philosophy, And The Order Of Knowledge. Bloomington: Indiana University Press.

Obenga, Theophile. 2004. "Egypt: Ancient History of African History," A Companion to African Philosophy. Wiredu, Kwasi. Ed. Malden: Blackwell.

Okafor, Fidelis. 1993. "Issues in African Philosophy Re-examined". International Philosophical Quarterly, Vol.33 No.1, pp.91-99.

Olela. Henry. 1998. "African Foundations of Greek Thought” African Philosophy: An Anthology ed. Emmanuel Eze. Malden: Blackwell.

Onyewuenyi, Innocent. 1976. "Is there an African Philosophy?" Journal of African Studies, 3; 513-528.

Oruka, H. Odera. 1975. "The Fundamental Principles in the Question of African Philosophy". Second Order, 4; 44-55.

--. 1991. Sage Philosophy: Indigenous Thinkers and Modern Debate on African Philosophy. Nairobi: Acts Press.

--. 1997. Practical Philosophy. Nairobi: East African Educational Publishers.

Outlaw, Lucius. 1996. On Race and Philosophy. New York: Routledge.

Presbey, Gail. 1997. "Who Counts as a Sage? Problems in the Further Implementation of Sage Philosophy". Quest, XI; 53.

Serequeberhan, Tsenay. ed. 1990. African Philosophy: The Essential Readings. New York: Paragon House.

Senghor, Leopold S. 1964. On African Socialism. London: Pall Mall Press.

--. 1995. "Negritude: A Humanism of the Twentieth Century" In Hord, Fred Lee and Jonathon Scott Lee Amherst eds. I am Because We Are: Readings in Black Philosophy. University of Massachusetts. Originally published in Africa Reader Vol.2. New York: Random House, 1970.

--. 1994. "Negritude: A Humanism of the Twentieth Century." In Williams, Patrick and Laura Chrisman eds. Colonial Discourse and Post-Colonial Theory: A Reader. New York: Columbia University Press, pp.27-35.

Wiredu, Kwasi. 1972. "On an African Orientation in Philosophy”. Second Order: An African Journal of Philosophy, 1; 3-13. 
--. 1998. "How Not to Compare African Thought and Western Thought". In African Philosophy: An Anthology, ed. Emmanuel Eze, 193-199. Malden: Blackwell Publishers.

--. 2003. A Companion to African Philosophy. Oxford: Blackwell.

Yai, O. 1977. "Theory and Practice in African Philosophy: the Poverty of Speculative Philosophy”. Second Order; 3-20 